\title{
Late Pleistocene and Holocene Glacier Extent in the Georgian Caucasus
}

\author{
Levan G. Tielidze ${ }^{1,2}$ \\ ${ }^{1}$ Department of Geomorphology, Vakhushti Bagrationi Institute of Geography, Ivane Javakhishvili Tbilisi State University, Tbilisi, \\ Georgia \\ ${ }^{2}$ Department of Earth Sciences, Georgian National Academy of Sciences, Tbilisi, Georgia \\ Email: levan.tielidze@tsu.ge, levani.tielidze@gmail.com
}

How to cite this paper: Tielidze, L.G. (2017) Late Pleistocene and Holocene Glacier Extent in the Georgian Caucasus. Open Journal of Geology, 7, 517-532. https://doi.org/10.4236/ojg.2017.74036

Received: March 10, 2017

Accepted: April 27, 2017

Published: April 30, 2017

Copyright $\odot 2017$ by author and Scientific Research Publishing Inc. This work is licensed under the Creative Commons Attribution International License (CC BY 4.0).

http://creativecommons.org/licenses/by/4.0/ (c) (i) Open Access

\begin{abstract}
This article presents the information of the Georgian Caucasus glaciation at the Late Pleistocene and Holocene period ( 126,000-11,700 calendar years ago). Our primary aim was to numerically reproduce the ice extent deduced from geological and geomorphological mapping. We used the analog method with the $30 \mathrm{~m}$ resolution SRTM DEM (Shuttle Radar Topography Mission Digital Elevation Model). In addition, the rates of glaciation of those times are identified based on the stadial moraines and erratic boulders. The current investigation has revealed that in the Late Pleistocene, the central and western Caucasus characterized the highest glaciation, while the eastern Caucasus boasted the lowest glaciated area, and in the southern Georgia's highland glaciation has almost the same form as there is in the Eastern Caucasus today. The longest glaciers were located in the Enguri (Nenskra $\sim 36 \mathrm{~km}$, Mulkhura $\sim 35.1 \mathrm{~km}$, Dolra $\sim 34.5 \mathrm{~km}$ ), Kodori (Sakeni $\sim 25 \mathrm{~km}$, Klichi $\sim 20 \mathrm{~km}$, Marukhi $\sim 17.3 \mathrm{~km}$ ) Rioni (Buba $\sim 23 \mathrm{~km}$, Kirtisho $\sim 20.5 \mathrm{~km}$, Jejora $\sim 17.5 \mathrm{~km}$ ) and Tergi (Devdoraki $\sim 38.5 \mathrm{~km}$, Suatisi $\sim 32 \mathrm{~km}$ ) river basins. We found, that topography thresholds related to the elevation and hypsometry of individual catchments controlled the gradient of the rate of glacier expansion in the domain at that time.
\end{abstract}

\section{Keywords}

Late Pleistocene, Holocene, Würm, Glacier Reconstruction, Analog Method, Caucasus Mountains

\section{Introduction}

One of the problematic issues of the studies of modern geographical science is the study of the paleoglacial issues. The changes in the natural physical-geographical conditions in the earth surface in the Upper Quaternary and Holocene 
are much depended on the glaciation dynamics. The glaciers in this period changed not only the structure of the geosphere, but they also established the new relationship between the geographical elements. It is known that in the Quaternary Age, the earth surface was subject to multiple glaciations and there are many views about the limits of their extension. Sometimes, these views complement each other, but sometimes they are mutually exclusive.

Basically, all research methods related to the reconstruction of the old glaciation are based on the analysis of the morpho-sculptural forms created by glaciers. The analysis of the glaciogenic forms does not always give the desirable result, particularly, when dealing with multiple glaciations. Moraines, as the forms of multiple glaciations, are not always maintained in the relief, or sometimes, a very strong glaciation removes the trace of the previous less strong glaciation from the earth surface. There are many such examples with the Caucasus and other mountainous massifs, where the most recent Würm glaciation removed the real traces of Mindel and Riss glaciations.

At the present stage, the glacial and fluvioglacial forms and deposits in the region of the Caucasus Mountain Range are quite common, indicating the quite large scales of glaciers extension. Particularly well preserved are the glacial forms in the basins of the major rivers of the Central and Western Caucasus and on the slopes of the Caucasus subranges [1]. Good distribution of the terminal moraines, existence of the associated trough forms and sometimes the allocation of the lateral moraines on the slopes of the river gorges, as well as the well preserved cirque forms allow identifying the borders of the glaciers extension quite accurately.

\section{Previous Studies}

After the famous scheme-the Paleo-Glacial Concept by A. Penk and E. Brukner (1901/1909) [2] almost all researchers (e.g. Reingard, [3]; Vardanyants, [4]; Tsereteli, [5]; Kovalev, [6]; Shcherbakova, [7]) tried to compare the Caucasus to the Alps, where the old glaciers were emerged in the plain from the foothill zone. Drawing such a picture for the Caucasus was acceptable for the researchers. They did not took into account that the Alps and the Caucasus are located at different latitudes, and what was common to the Alps at a spatial scale, could not be identical to the Caucasus. Surely, the glaciation both, in the Alps and Caucasus was of coincided character. Coincided was the fact as well, that the glaciation of that period was the strongest, but their expansion limits could not be identical. There were many opponents to this view, who considered that comparing the Alps with other mountainous regions was inappropriate. Solving this issue is problematic and urgent even today.

As far back as in 1956 L. Maruashvili, on assessing critically the study of old glaciers in the Caucasus in his monograph [8], indicates the mistakes accompanied their works. L. Maruashvili criticizes the Alpine school followers-A. Reinhardt [3] and L. Vardaniantz [4], who, based on the Alpine Scheme, compiled the paleoglacial map of the Caucasus (a paleographic scheme of the Caucasus in the glaciation epoch). These materials were the basis for all following research- 
ers. This view was unanimously shared almost by everyone.

The Alpine Scheme was opposed by L. Maruashvili, who refused to adapt and disseminate it to the Caucasus and who stated that the glaciation in the Caucasus was weaker than it was stated by the representatives of this school. L. Maruashvili considered that in the Quaternary the glacier tongues flowed down to the height of $\sim 1000-1500 \mathrm{~m}$ in the Western and Central Caucasus (Bzipi-Kodori basin) and to $\sim 2000-2500 \mathrm{~m}$ in the Eastern Caucasus (Tergi, Asa). The snow line depression made $\sim 600-800 \mathrm{~m}$.

In the opinion of D. Tsereteli [5], the glaciation of the Caucasus can be compared to that of the Alps and even to other mountainous regions. In his opinion, the course of the glaciation in the Caucasus is behind the Alps glaciation by a half cycle. He considered that the glaciers in the Caucasus descended quite below (if judging by Tsebelda moraine), and the snow line depression made $\sim 1200 \mathrm{~m}$. This opinion is close to all opinions about the Alps and to our mind, it is generally true. As for the descending of the glacier tongues in the basins of the rivers of Enguri and Rioni to $\sim 800-1000-1100 \mathrm{~m}$, this point of view is correct and is proved by the existence of the moraine complex there.

The Nenskra, Mestia, Dolra and Ushguli moraines are located at the different altitudes in the Enguri River basin. Due to this, D. Tsereteli [5] considered them to be of different ages (stages). To our mind, this opinion needs further specification.

R. Khazaradze [9] studied the questions of glaciation by using the petropraphic method. His works give the borders of the glacier extension in the basins of the rivers of Georgia with the locations of the erratic boulders.

The old Caucasus glaciation is considered in the works by G. Abich [10], A. Reinhardt [11] [3], I. Kuznetsov [12], L. Vardaniantz [13] [4], B. Klopotovskiy [14], K. Paffenholz [15], S. Nemanishvili [16], G. Dondua [17], N. Astakhov [18], E. Milanovskiy [19], N. Dumitrashko [20], P. Kovalev [6], D. Tabidze [21], D. Tsereteli [5], L. Serebruanny and A. Orlov [22], R. Gobejishvili [23] and etc.

Unfortunately, the problems of Caucasus Pleistocene glaciation are still far from being resolved. There are very few absolute dates for the Late Pleistocene and Early Holocene, and even the Late-glacial and Post-glacial pollen spectrum is not dated properly. Nevertheless, there are two major schools established around the old Caucasus glaciation: 1) the followers of the Alpine school think that the glaciation during the Würm was of a sheet or semi-sheet with the snow line depression of $\sim 1100-1300 \mathrm{~m}$ and the glacier tongues descending to a very low hypsometric level. The glaciers in the river gorges joined each other and emerged in the foothill zone as a single tongue (the rivers of Tergi, Enguri, Baksan, Cherek, Kuban, Kodori and etc.); 2) By the opinion of another group of scientists, the glaciation was weak during the Würm, with the snow line depression at $\sim 600-800 \mathrm{~m}$, and the glacier tongues descending to $\sim 1500-2000 \mathrm{~m}$ (from Kodori to Tergi).

Both opinions are based on certain factual material and at one glance, it is difficult to assess which opinion is right, though, we think that there is a truth in both opinions and their comparative analysis will yield in the desirable result. 


\section{Methods}

For this purpose, we decided to study these questions using analog method following the Gobejishvili et al., [24] approach. The essence of the analog method is as follows: in case of similar natural conditions (factors), the same process or phenomenon can be studied in one region and apply the obtained information to another region. The analog method is widely used in glaciology and geomorphology. For instance, let us consider the glaciers located on the southern slope of the Caucasus. If considering a valley glacier and studying its thawing or accumulation, we will see that the numerical data typical to it can be applied to the similar glaciers found in the adjacent basins. The glaciologists call such a glacier the model glacier.

When reconstructing the morphology and sizes of the old glaciation, an objective difficulty is that the trace of old glaciation is slightly preserved in the relief and many sedimentary forms very much look like the glacial forms by their appearance. The trough form of the valley at many locations is modified due to the weathering, erosion or denudation processes. Under their impact, the lateral moraines on the slopes are absolutely removed, or are survived as fragments. The terminal moraines are preserved not so well, as they are washed off under the action of fluvioglacial or mudflow currents. Due to the active exogenous processes, the old glacial material is transported to the lower hypsometric levels and forms a false image of the real extension of the glaciers.

Despite the many-year detailed studies, the genesis of these formations is impossible to specify by using the traditional glacial-geomorphological approach. Because of this there are essential differences in the identification of the morphology and scale of the glaciation in many mountainous regions of the world.

It is important that the data on modern glaciers are not used in solving the paleo-glacial problems. In order to fill this gap, we studied the modern glaciers of Georgia.

We identified the link between the length of the modern glaciers and their feeding firn basins. The analysis of aerial images and cartographic materials showed that the tongues of the valley glaciers are fed from the firn within the vast cirque forms located at higher altitudes. The larger the firn basin is, the longer the glacier is. If the glacier of a certain length corresponds to the feeding area of the modern glacier, it is natural that the feeding area of the old glacier would have formed a glacier of a certain length [24]. This idea can be expressed by a directly proportional dependence formula:

$$
\frac{L c}{S c}=\frac{L d}{S d}
$$

where the $L c$-is the length of the modern glacier, $S c$-is the area of the firn basin of the modern glacier, $L d$-is the length of the Pleistocene glacier and $S d$-is the area of the firn of the Pleistocene glacier.

In this formula, the values of $L c$ and $S c$ are identified by using the topographic maps for the valley glaciers of some mountains in Georgia and Eurasia (Tian Shan, Spitsbergen, Tibet, Himalayas) [23]. 
For comparison purposes, we classified the gained quantitative indexes by their values and grouped them. We singled out four groups of glaciers, which clearly differ from each other with the above mentioned dependence. We denoted this dependence by coefficient $K$ :

$$
\frac{L c}{S c}=K
$$

The first group included the hanging-valley and simple-valley glaciers; for them $K=0.81$ (with the correlation coefficient of 0.96 ); the second group included the simple-valley glaciers with a multi-chamber firn with $K=0.50(0.95)$; the third group included the compound-valley glaciers with $K=0.33$ (0.99); and the fourth group included the branched glaciers with $K=0.13(0.86)$.

Today there are no glaciers of the fourth group found in the Caucasus. Classical examples of such glaciers are Inylchek, Koendi and Mushketov in Tian Shan, Rongbuk-in the Himalayas and etc. Further division of the glaciers of this group for the other mountainous regions (Alaska, Karakorum, Hindu Kush) will be necessary to improve the accuracy of the data (according to the number of branches composed the glacier). For the higher accuracy the coefficient is better to calculate for the individual types of the glaciers.

Based on the data gained for individual groups, a nomogram showing the relation between the area of the glacier firn basin and the glacier length was drafted. After defining coefficient $(K)$ the proportional dependence formula will be as follows:

$$
\frac{L d}{S d}=K \text {, then } L d=S d \times K \text {. }
$$

In this formula, the $S d$-is the feeding area of the old glacier, i.e. it is the cirque of the old glacier, which was the source of feeding the glacier.

In addition, we used the geomorphological, cartographical, petrographical and aerial images decoding methods (in order to identify the areas of the distribution of moraines). The complex application of these methods led us to the different method of study, which will allow identifying the limits of the old glaciation according to the individual orographic units and the river basins, which finally gives the full picture of the Würm glaciation extension in the Georgian Caucasus. Based on these data we compiled the map of the Würm glaciation of the Georgian Caucasus (Figure 1).

\section{Results}

The morphological and morphometric analysis of the relief and processing of modern aerial images showed that the old cirques developed in the axial zone of the Caucasus built with crystal rocks are well preserved in the relief. The old cirques are mostly originated during the glaciation of the Late Pleistocene. This glaciation is known as the Würm Glaciation in literature. Post-Würm stage glaciation led to the slight re-deepening of the existing cirque. We mapped almost all glacial cirques and measured their areas. In addition, we identified the height of the lower limits of the cirques. To our opinion, the height of the lower 


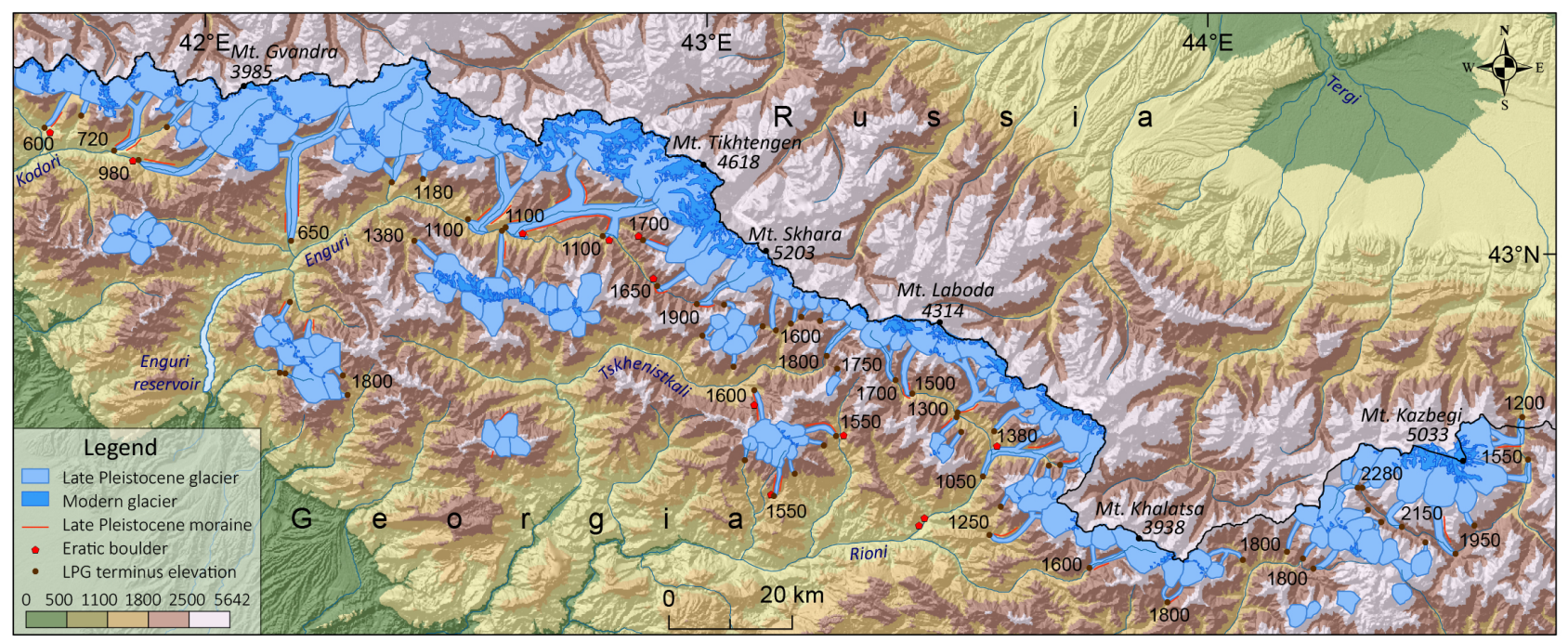

Figure 1. Modern and Late Pleistocene glaciers of the Kodori, Enguri, Rioni and Tergi River basins.

limits of the cirques is the indicator of the firn line location. Based on the gained materials, we calculated the lengths of the Late Pleistocene glaciers, the altitudes of their terminus and location of the firn lines (Figure 1, Table 1).

\subsection{Late Pleistocene Glacier Extent}

\subsubsection{Western Caucasus}

The Late Pleistocene glaciation in the Western Caucasus was of a mountainvalley type. The principal glaciation center was the Caucasus watershed, while the other centers were found in the Gagra, Bzipi, Chkhalta (Apkhazeti) and Kodori subranges [25]. Despite the fact that the Western Caucasus is not high hypsometrically, the signs of the old glaciation are well preserved in the form of cirques and moraines. The lower threshold of the cirque forms is located at the altitude of $\sim 1900-2100 \mathrm{~m}$. This altitude during the Würm was the lower limit of the nival zone. This evidences that in the Late Pleistocene the firn line depression in the river basins of the Western Caucasus was $\sim 1000-1200 \mathrm{~m}$. The largest glaciers on the southern slope of the Caucasus descended to $\sim 600-700 \mathrm{~m}$. The glaciers were of a compound-valley type and they reached $\sim 16-17 \mathrm{~km}$ in length. The largest glacier was in the Sakeni valley (with the length of $\sim 25 \mathrm{~km}$ ).

Quite a strong glaciation occurred on the southern slopes of the Western Caucasus watershed during the Würm. Large glaciers descended to the bottom of the Kodori River and ended at different hypsometrical levels (Figure 1, Table 1).

\subsubsection{Central Caucasus}

The high hypsometrical location of the Central Caucasus, the morphological peculiarities of the relief and climatic conditions determine the development of intense glaciation in the Late Pleistocene and Holocene. The lower threshold of the cirques formed by the glaciers of the Late Pleistocene is located at different hypsometric heights. Despite this, it is well seen that the height of the lower threshold of the cirques in the Central Caucasus increases from $\sim 2100 \mathrm{~m}$ (the Nenskra River basin) to $\sim 2500 \mathrm{~m}$ (the Tergi River basin) from the west to the 
Table 1. Morphometric indicators of the Late Pleistocene glaciers on the Georgian Caucasus.

\begin{tabular}{cccc}
\hline Name of the glacier & Old cirque area, $\sim \mathrm{km}^{2}$ & Length, $\sim \mathrm{km}$ & $\begin{array}{r}\text { Terminus elev } \\
\text { a.s.l. } \sim \mathrm{m}\end{array}$ \\
\hline Western Caucasus & & & \\
Kodori River basin & 36.0 & 17.3 & 1450 \\
Marukhi & 7.7 & 6.7 & 1000 \\
Sopruju & 8.2 & 7.2 & 900 \\
Adeba & 20.8 & 8.7 & 760 \\
Atsiashi & 27.0 & 14.0 & 600 \\
Ptishi & 12.7 & 7.0 & 1200 \\
Khetskvara & 59.0 & 20.0 & 720 \\
Klichi & 17.5 & 11.5 & 1400 \\
Ghvandra & 89.0 & 25.0 & 980 \\
Sakeni & 8.0 & 7.5 & 1700 \\
Adange & & &
\end{tabular}

\section{Central Caucasus}

Enguri River basin

$\begin{array}{cccc}\text { Nenskra } & 275.0 & 36.0 & 650 \\ \text { Nakra } & 63.0 & 20.0 & 1180 \\ \text { Dolra } & 105.0 & 34.5 & 1050 \\ \text { Mulkhura } & 270.0 & 35.1 & 1150 \\ \text { Adishi } & 24.0 & 19.4 & 1700 \\ \text { Khalde } & 31.0 & 15.5 & 1650 \\ \text { nguri (Skhara) } & 35.0 & 17.5 & 1900 \\ \text { Lailchala } & 23.0 & 11.5 & 1100 \\ \text { Laila } & 17.0 & 13.5 & 1380 \\ \text { Tkheishi } & 7.0 & 5.6 & 1450 \\ \text { Kveishkhi } & 4.5 & 3.6 & 1600 \\ \text { Didgali } & 6.0 & 4.8 & 1350 \\ \text { Magana } & 7.5 & 6.0 & 1450 \\ \text { Khobistskali } & 8.0 & 6.4 & 1800\end{array}$

Rioni River basin

$\begin{array}{cccc}\text { Koruldashi } & 15.0 & 11.7 & 1600 \\ \text { Zeskho } & 9.0 & 7.5 & 1600 \\ \text { Shari } & 11.5 & 9.0 & 1800 \\ \text { Edena } & 16.5 & 14.1 & 1650 \\ \text { Zopkhito } & 21.5 & 17.4 & 1500 \\ \text { Kirtisho } & 42.0 & 20.5 & 1300 \\ \text { Notsara } & 14.8 & 12.6 & 1280\end{array}$




\section{Continued}

\begin{tabular}{cccc}
\hline Boko & 20.9 & 18.0 & 1100 \\
Buba & 40.5 & 23.0 & 1050 \\
Chanchakhi & 13.1 & 11.0 & 1750 \\
Gharula & 17.5 & 14.0 & 1250 \\
Jejora & 19.8 & 17.5 & 1600 \\
Latashuri & 11.0 & 8.5 & 1500 \\
Sokhortuli & 7.5 & 6.0 & 1600 \\
Ghobishuri & 8.5 & 7.0 & 1800 \\
Shodura & 5.4 & 4.0 & 1600 \\
Liakhvi River basin & & & \\
Zekara & 8.5 & 7.0 & 1900 \\
Kveshelta & 10.0 & 8.0 & 1800 \\
Jomagi & 11.2 & 9.1 & 1550 \\
Sba & 9.2 & 7.5 & 1800 \\
Cheliata & 8.0 & 6.5 & 1850 \\
Kalasani & 11.0 & 9.0 & 1800
\end{tabular}

\section{Eastern Caucasus}

Tergi River basin

Devdoraki

Gergeti

Mna

Suatisi

Tergi headwater

Khdestskali

Chaukhi

Aragvi River basin

Abudelauri

Asa River basin

Chkhotani

Akhieli

Bisna

Arghuni River basin

Shatili

Kamkhi

Pirikita Alazani River basin

$\begin{array}{cc}\text { Tebulo } & 14.0 \\ \text { Amugho } & 7.5 \\ \text { Larovani } & 6.8 \\ \text { Kachu } & 11.5 \\ \text { Didkhevi } & 13.7 \\ \text { Cheros Khevi } & 10.0 \\ \text { Diklo (Khao) } & 14.5\end{array}$
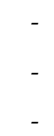

17.0

18.0

10.0

11.9

10.5

9.5

5.5

14.0

7.5

6.8

11.5

13.7

10.0

4.5
14.2

15.0

5.7

11.5

6.5

7.3

5.5

1220

1550

1950

2150

2270

2140

2200

1600

1700

1750

2060

1800

1900

$4.5 \quad 2100$

$11.0 \quad 2400$

$6.0 \quad 2500$

5.52560

$6.0 \quad 2200$

$7.0 \quad 2220$

$5.0 \quad 2140$

$7.0 \quad 2100$ 
east. The main glaciation center in the Late Pleistocene was the watershed of the Caucasus range (Figure 1, Table 1). There were quite large glaciers in the Svaneti range, while the relatively small valley and cirque glaciers were formed in the other subranges of the Caucasus (Samegrelo, Lechkhumi, Shoda-Kedela, Racha, Germukhi and Kharuli). Due to the hypsometric conditions of the subranges, there was a glacial zone developed here as the individual areas. On the other hand, the entire crest zone was included in the nival zone. As the subranges are of general Caucasian or lateral direction, the glaciation degree here is determined by the relief hypsometry, morphology and distance from the Black Sea. The glaciation in the Svaneti range had a sharply asymmetrical nature in the Late Pleistocene and still has today, what in our opinion, is caused not only by exposition, but also by the morphological conditions of the relief.

Among the river basins located on the southern slope of the Central Caucasus, the Enguri River basin was distinguished by the intense glaciation. Our studies showed that in the Enguri River gorge, especially the glaciers descending from the basins of the right tributaries blocked the Enguri River gorge and sometimes followed it for 1 to $3 \mathrm{~km}$ (the rivers of Dolra, Mulkhura, Khalde and Lailchala). In other basins (the Nenskra, Nakra, Adishchala and Laila) massive valley glaciers were developed during the Würm, but they did not emerge in the Enguri River bed.

\subsubsection{Eastern Caucasus}

The relief of the Eastern Caucasus with its morphological and morphometric properties is behind the Central Caucasus, resulting in, together with the climatic factors, the small scales of glaciation [26] both, today and in the entire Upper Quaternary and Holocene. As we have seen above, the modern glaciers are associated with the individual high-elevated massifs. A similar picture was observed in the Würm, as by our calculations, the lower limit of the glacial zone in the Würm was at the height of $\sim 3400-3600 \mathrm{~m}$. The nival zone was presented at a vast area in the Eastern Caucasus, but it was not extended over the entire territory. It was spread continuously only along the Caucasus watershed range. As for the Würm glaciers, they were linked with the massifs with the heights of about $3400-3600 \mathrm{~m}$.

The glaciation in the Würm in the Eastern Caucasus had the properties similar to those of glaciers on the southern slope of the Central Caucasus at present.

The Tergi River head and the basins of its tributaries are located on the northern slope of the Eastern Caucasus. Here, the northern exposition of the slope plays a certain role in the origination of both, modern and Würm glaciations. The old cirque forms here evidence that during the Würm there were quite strong glaciers in the basins of the right tributaries of the Tergi River with their tongues outcropping into the bottom of the Truso basin (the lower threshold of the glacial cirques is at the height of $\sim 2500-2600 \mathrm{~m}$ ). The longest glaciers were in the head of the Tergi River and the Desistskali gorge. Their length was $\sim 10-12 \mathrm{~km}$ (Figure 1, Table 1). 


\subsubsection{Southern Georgia's Highland}

Under the southern Georgia's highland, we consider all those ranges and plateaus, which are located to the south of the intermountain plain: the ranges of Adjara-Imereti, Shavsheti, Arsiani, Trialeti, Samsari and Javakheti and the Erusheti upland. In the elevated part of these orographic units there were small glaciers developed during the Late Pleistocene evidenced by the glacial forms remained there.

All previous researchers indicate the presence of old glacial forms there (B. Klopotovskiy, [14]; L. Maruashvili, [8]; D. Tabidze, [21]; D. Tsereteli, [5] and others). The only difference among them is in the scales of glaciation.

Our studies showed that in the southern Georgia's highland the Würm glaciation has almost the same form as there is in the Eastern Caucasus today. In the Würm, the firn line was located in the Adjara-Imereti range at the lowest altitude, at $\sim 2200-2300 \mathrm{~m}$, and in the Samsari and Javakheti ranges-at the highest altitude, at $\sim 2500-2700 \mathrm{~m}$. Neither of the ranges reached the glacial zone. However, the nival zone was presented quite clearly, where small cirque and valley glaciers were formed under the influence of the atmospheric precipitations. These glaciers were concentrated at the small sections of the ranges with their heights more than $\sim 2400 \mathrm{~m}$, for example: Sakornia, Mepistskaro and Loboroti in the Adjara-Imereti range; Karakaya and Mount Sakvelo-in the Trialeti range; Kanli Dagi-in the Arsiani range, and Abuli, Samsari and others-in the Samsari range.

The degraded cirque forms remained there are of small sizes and accordingly, the glacier lengths were short-up to $\sim 3.0 \mathrm{~km}$. The largest glaciers were in the Samsari range. Valley glaciers were developed around the volcanic peaks of $\mathrm{Ab}$ uli and Samsari; their maximum length did not exceed $\sim 5-5.5 \mathrm{~km}$ [8]. The cirque forms start at the height of $\sim 2600-2700 \mathrm{~m}$. The genesis of the small lakes at this location is associated with the glacial and periglacial processes. The forms typical to the nival zone, both of Würm and post-Würm, are well preserved in the Samsari and Javakheri ranges. The sediments of old rock glaciers are a good evidence of this.

\subsection{Holocene Glacier Extent}

In contrast to a hypothesis of a stable Holocene climate, as indicated by oxygen isotope records from the Greenland Ice core [27] and northern Alpine lake sediments [28], a growing number of studies (e.g. Mayewski et al., [29] and references therein) have demonstrated that distinct periods of climate change occurred repeatedly throughout the Holocene [30]. Mountain glaciers are potentially good climatic indicators, but most of the information on the dynamic responses of mountain glaciers to past climate changes comes from European glaciers which only form $3 \%$ of the world's glaciated area [31]. Knowledge of the Holocene glacier behaviour of remote and inaccessible mountain regions, often characterized by a high degree of glaciation, is rather limited. For better understanding of the global spatial-temporal glacier variability and throughout the 
Holocene, it is very important to study worldwide glacier dynamics, including the Caucasus Mountains.

There were several stadial glaciations in the Holocene and their paleoglacial study allows reconstructing the landscape zones and paleo-climate. With this purpose, the glacial deposits were studied on the southern slope of the Caucasus range and their correlation to the river terraces has been conducted. The absolute age $\left({ }^{14} \mathrm{C}\right)$ of organic deposits has been identified at several locations.

The trace of the stage glaciation in the Late Holocene (Neogene) is particularly well preserved in the Kodori River basin in the form of lateral and terminal moraines. The signs of an early times stadial glaciation are survived in the Sakeni River gorge, while in other gorges their traces are washed out or they are in the form of the separate fragments making it difficult to identify their number and limits of expansion.

The first stadial moraine in the Sakeni River gorge is at the height of $\sim 1550$ $1600 \mathrm{~m}$, in the environs of its right tributary of Olbaki [8]. At a distance of $\sim 1.5$ $\mathrm{km}$ above it, there is another moraine, which is seen quite well in the relief.

At the heights of $\sim 1860 \mathrm{~m}$ and $\sim 1930 \mathrm{~m}$, there are two moraine complexes in the Sakeni River gorge distanced by $\sim 500-600 \mathrm{~m}$ from each other. The upper (fourth) moraine of them is well seen in the relief.

After the mentioned stadial glaciation there was a lake; after it was filled up, a straight, slightly inclined and flat-bottomed valley was originated [8]. The origination of the fourth stadial moraine and the lake should have taken place at the beginning of the Late Holocene. Conditionally, we attributed the third moraine to the Upper Holocene. During this stadial glaciation, the Sakeni and Achapara glaciers were merged with each other.

There are two stadial moraines in the basins of almost all glaciers in the Sakeni River gorge. The distance between them is about $0.5 \mathrm{~km}$. The young lateral and terminal moraines of them belong to the LIA maximum glaciation, and the intensely denuded moraine in the relief belongs to the historical stage ( 2000 2500 years) [23].

In the Sakeni River gorge we see the traces of six stadial glaciations. The $1^{\text {st }}$ $3^{\text {rd }}$ moraines of them were formed in the Late Pleistocene and Early Holocene, and the $4^{\text {th }}-6^{\text {th }}$ stadial moraines were originated during the Neo-glacial (Late Holocene) glaciation.

The stadial moraines of the Late Holocene age are remained in the heads of the rivers of Klichi and Marukhi at the height more than $\sim 1900 \mathrm{~m}$ above sea level. The $4^{\text {th }}$ stadial moraine is located at the height of $\sim 1900-1950 \mathrm{~m}$; the $5^{\text {th }}$ historical stadial moraine is remained at the height of $\sim 2150-2200 \mathrm{~m}$ and the $6^{\text {th }}$ LIA maximum moraine is remained at the height of $\sim 2250-2300 \mathrm{~m}$ and is clearly seen in the relief. It is distanced from the glacier by $\sim 1.0-1.5 \mathrm{~km} \mathrm{[23]}$.

The trace of stadial glaciation in the Enguri River basin is best fixed in the gorges of the rivers of Mulkhura and Adishchala.

We distinguish the six stadial glaciations in the Mulkhura River gorge. A full spectrum of the stadial moraines is seen in the Mestiachala River gorge, on the 
western slope of Gvalda range, near the airport. The lateral stadial moraines are fixed as steps, while the Würm moraine is clearly seen as a hillock; the Würm moraine is found as a hillock on the right side of the gorge, as well. The trace of $\left(1^{\text {st }}-2^{\text {nd }}\right)$ two stadial glaciations is fixed as a step at the height of $\sim 1750 \mathrm{~m}$ and $\sim 1810 \mathrm{~m}$ above sea level. Below that, at the height of $\sim 1650$ and $\sim 1620 \mathrm{~m}$, there are two more steps built with glacial material. The $4^{\text {th }}$ moraine of them is in the form of a hillock, which is stretched to the village of Spardishi. The moraine of the same stage is found at the village of Lanchvali, which is covered with delluvial cones. Lanchvali and Spardishi lateral moraines arch near the Lanchvali Bridge. The glacial boulders here evidence that during the $4^{\text {th }}$ stage, the glacier ended at this location. However, the terminal moraine is washed due to the river action [32] [33].

The moraine material in the environs of a former touristic base in Mestia is a continuation of the $3^{\text {rd }}$ stadial moraine, while its morphological continuation is found even higher, in the Mulkhura-Mestiachala flat watershed.

The traces of the $1^{\text {st }}$ and $2^{\text {nd }}$ stadial glaciations are remained on the left slope of the Mulkhura River, in front of Mestia-Lenjeri (Figure 2). The $2^{\text {nd }}$ stadial moraine is presented as a hillock descending to the gorge bottom above Lenjeri. The trace of the $1^{\text {st }}$ stadial glacier is seen very slightly as individual steps and reaches the village of Kashveti. During these stages the Tviberi and Lekhziri glaciers were merged with each other.

The fragments of the $5^{\text {th }}$ (historical stage) stadial moraine are remained in the environs of the village of Lavladashi and as fragments on the left side up along the gorge. There are a number of granite boulders on the both sides of the gorge, both, in the floodplain environs and beyond it (Figure 3 ). It should be noted that a morphologically well-seen debris cone in front of Lavladashi gorge is of three-step identified through the correlation to the glaciation in the Neo-Glacial (Late Holocene) period. During the LIA maximum the Lekhziri and Chalaati glaciers did not merge with each other. The Chalaati glacier descended to the Lekhziri River bed and created the plug. The $6^{\text {th }}$ stadial moraines are clearly seen in the relief.

The trace of the stadial glaciation in the Mulkhura River basin is best re-

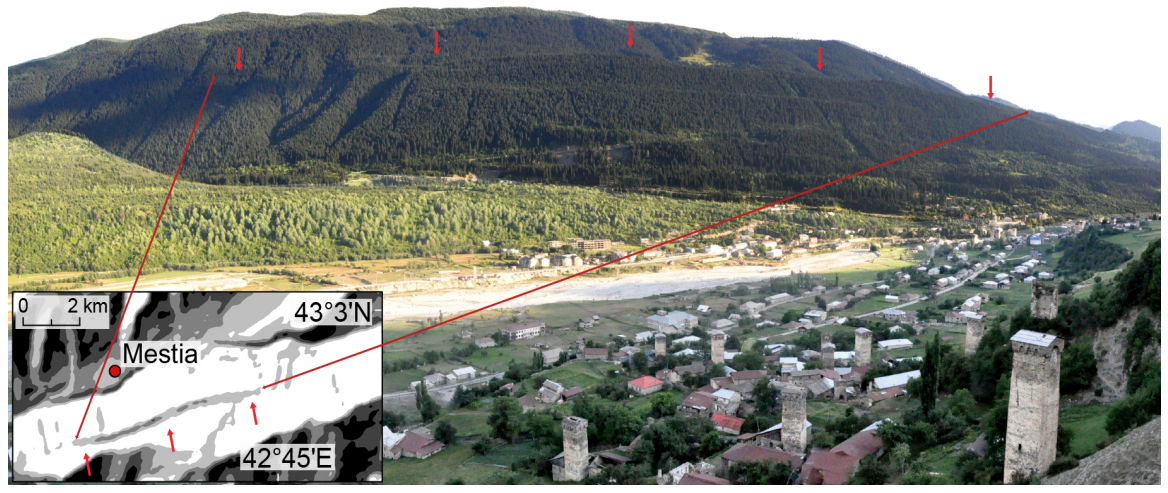

Figure 2. The trace of the $1^{\text {st }}$ and $2^{\text {nd }}$ stadial glaciations on the left slope of the Mulkhura River in front of Mestia-Lenjeri (photo by: L. G. Tielidze). 


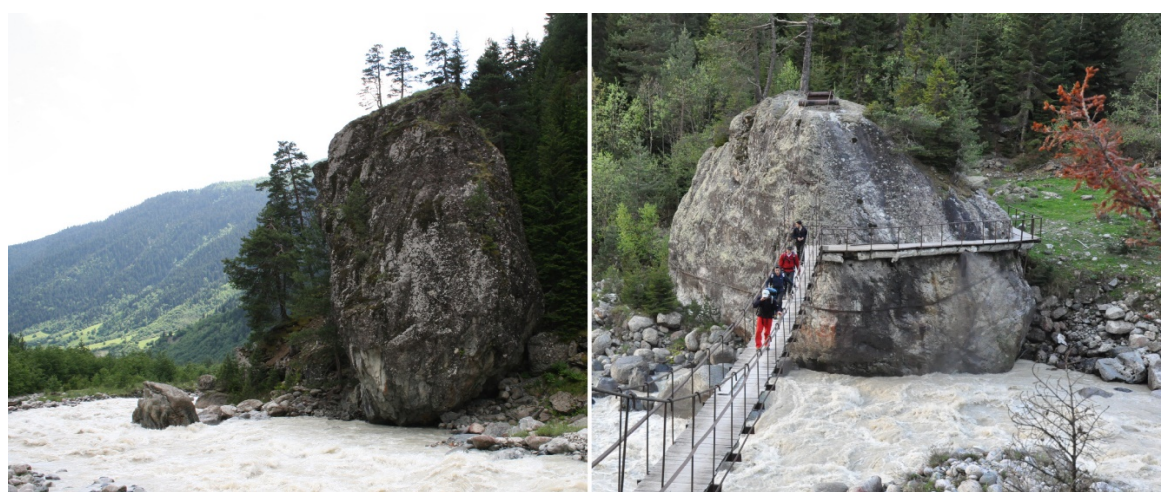

Figure 3. Erratic boulders in the Mestiachala River valley (photo by: L. G. Tielidze).

mained in the environs of the Ughviri Pass and Lagvzalieri area. The relative height of the Ughviri Pass is $300-350 \mathrm{~m}$ from the Mulkhura gorge. During the stadial glaciation (the $1^{\text {st }}$ and $2^{\text {nd }}$ stages) the thickness of the Tviberi-Tsaneri glacier was more and one flow of the glacier (the Nageba glacier) moved to the Enguri River gorge. On the slope of the Enguri River, within the Würm moraines, there are two series of lateral moraines and a corresponding terminal moraine. Such state of moraines evidences that the glacier flow of these stages did not reach the bottom of the Enguri River. On the northern slope of Ughviri two lateral stadial moraines $\left(3^{\text {rd }}-4^{\text {th }}\right)$ are identified. One of them is located immediately near the watershed and another one is located in the environs of the Ughviri Lake (the lake itself is originated during this stage).

On the right slope of the Mulkhura River gorge, at Lagvzalieri location, at the height of $\sim 1900$ - $1950 \mathrm{~m}$, there is a $\sim 1.0$ - $1.5 \mathrm{~km}$ long moraine, which is located at the same hypsometrical height as Ughviri $3^{\text {rd }}$ and $4^{\text {th }}$ moraines. Even higher $(\sim 2120-2150 \mathrm{~m})$, there is another moraine, which in our opinion, is synchronous to the $1^{\text {st }}$ and $2^{\text {nd }}$ stages of Ughviri. The fragments of the terminal moraines of the $3^{\text {rd }}$ and $4^{\text {th }}$ stages are found on the territory of Mestia community (at the beginning of the Mulkhura gorge), at the height of $\sim 1450 \mathrm{~m}$.

The $5^{\text {th }}$ stadial moraine is located at the confluence of the rivers of Tviberi and Tsaneri. This moraine is morphologically seen in the relief and without a doubt it was formed by the action of the Tviberi glacier. Corresponding to it the moraine is found in the Tsaneri gorge, in the environs of the mineral waters. These moraines belong to the historical stage. The LIA maximum moraine is completely presented in the basins of all glaciers.

Identification of the age of a stadial moraine became possible only by correlating them to the river terraces. [23] sampled an organic substance (wood) from $\sim 8-10 \mathrm{~m}$ high terrace at the village of Jorkvali (the Enguri River gorge) with its age ( 5000 \pm 200 years) identified at the Tallinn radiocarbon laboratory. This terrace seems to be formed at the end of the Middle Holocene. This terrace of the given height is fixed at many locations in the Enguri River gorge (villages of Pari, Tskhumari, Lenjeri, etc.) and ends at the $4^{\text {th }}$ stadial moraine near the settlement of Mestia.

There is a $2-3 \mathrm{~m}$ high terrace found at Mestia and at the village of Lenjeri, 
which stretches long the gorges of the rivers of Mestiachala and Mulkhura. In the Mestiachala River gorge an airport and a new settlement are built on this terrace, which is morphologically clearly seen and stretches to the village of Lavladashi, where it is transformed into the historical stadial $\left(5^{\text {th }}\right)$ moraine. In the Mulkhura River gorge this low terrace is seen everywhere and is transformed into the stadial moraine at the confluence of the rivers of Tviberi and Tsaneri.

The analysis of the materials allows making the following conclusion: the $4^{\text {th }}$ $5^{\text {th }}$ and $6^{\text {th }}$ stadial moraines were originated in the Late Holocene (Neo-glacial period).

\section{Conclusion}

In this paper, we have presented the Late Pleistocene and Holocene glacier simulation of the entire Georgian Caucasus, using analog method and guiding constraints from geological data. Our experimentation has explored that the Late Pleistocene glaciation of the Georgian Caucasus consisted of valley glaciers, with ice caps only on some peaks. The glacier tongues which terminated at the lowest altitudes were those of the Ptishi and Nenskra Glacier on the south slope at $\sim 600$ and $\sim 650 \mathrm{~m}$ a.s.l. respectively. Tongues of other large glaciers descended down to 1600 - $1200 \mathrm{~m}$ a.s.l. The firn line in the Central Caucasus was found at 2000 $2500 \mathrm{~m}$ in the Late Pleistocene, increasing in the altitude from west to east. This implies that the firn line in the Caucasus was depressed by $1200-1300 \mathrm{~m}$ during the Late Pleistocene (allowing for neotectonic activity), and the depression increased from west to east. This is equivalent to a decline in mean annual temperature of ca. $7^{\circ} \mathrm{C}-8^{\circ} \mathrm{C}$ (with a gradient of $0.6^{\circ} / 100 \mathrm{~m}$ altitude). We expect that the approach used in this article is a useful technique for determination the Late Pleistocene glacier parameter, configuration and geometries.

\section{References}

[1] Tielidze, L. (2016) Glaciers Catalog of Georgia. Publishing House "Samshoblo", Tbilisi, 116

[2] Penck, A. and Bruckner, E. (1901/1909) Die Alpen im Eiszeitalter, 3 Vols. Tauchnitz, Leipzig, 1199 p.

[3] Reingard, A.L. (1937) About the Problem of the Stratigraphy of the Glacial Time of the Caucasus. Transactions of International INQUA Congress Transactions, Section M 1, 9-31. (In Russian)

[4] Vardaniants, L.A. (1937) The Ancient Glaciation of the Rivers Iraf (Urukh) and Tsey (Central Caucasus). Proc. State Geogr. Soc., 69, 537-562. (In Russian)

[5] Tsereteli, D.V. (1966) Pleistocene Deposits of Georgia. Publ. House "Metsniereba", Tbilisi, 582 p. (In Russian)

[6] Kovalev, P.V. (1961) Modern and Ancient Glaciation Enguri River Basin. Mat. Kavkaz. Eksped. T. 2. Xarkov. Izd XGU. (In Russian)

[7] Shcherbakova, E.M. (1973) The Ancient Glaciation of the Great Caucasus. Moscow University Press, Moscow, 272 p. (In Russian)

[8] Maruashvili, L.I. (1956) Advisability of Revising Existing Paleogeographic Conditions of the Glaciation Age in the Caucasus. Publ. Academy of Sciences of the Geor- 
gian SSR, Tbilisi. (In Russian)

[9] Khazaradze, R.D. (1971) Relief, Continental Sediments and Pleistocene Glaciation Enguri River basin. Avtoreferat kand, Disertacii, Tbilisi. (In Russian)

[10] Abich, H. (1865) The Study of Current and Ancient Glaciers of the Caucasus. Cb, cvedenii o Kavkaze, T. 1, Tiflis. (In Russian)

[11] Reinhardt, A.L. (1936) Ice Age of the Caucasus and Its Relation to the Glaciation of the Alps and the Altai. tr. II. mejd. konf. po izuchenie chetvertichnogo perioda evropi. L-M, bip. 2. (In Russian)

[12] Kuznetsov, I.G. (1931) Geological Structure Shamshovy Resort to the Chanchakhi River Basin. tr. vsesoiuznogo geolog, razvitia obedinenia. vipusk 151. (In Russian)

[13] Vardaniants, L.A. (1930) On a New Method Estimate Depression Snow Line in Relation the Study Stage Glacier Retreat Mining Group Adai-Hoch in the Central Caucasus. Izd. RGO. T. 62. Vip. 2 (In Russian)

[14] Klopotovskiy, B.A. (1949) Khorlakelskaya Moraine. Soobsh. AN. GSSR. T. 10, N.6. (In Russian)

[15] Paffenholz, K.N. (1958) The New Stratografic Data of Kazbegi District and the Keli Volcanic Plateau (Central Caucasus), and Ancient Glaciation in This Area. Sovetskaia geologia, N. 12. (In Russian)

[16] Nemanishvili, S. (1962) Geomorphology of the Northern Part of Lower Racha. Vakhushtis saxelobis geogr. Institutis shroebi, T. 12. (In Georgian)

[17] Dondua, G. (1959) Geomorphology of Jejora nad Gharula River Basins. Vaxushtis saxelobis geografiis isntitutis shromebi, T. 12. (In Georgian)

[18] Astakhov, N.E. (1973) Structural Geomorphology of Georgia. Pub. House "Metsniereba", Tbilisi. (In Russian)

[19] Milanovskiy, E.E. (1960) Traces Late Pleistocene Glaciation in the High Part of the Central Caucasus. Dokladi an SSSR. T. 130, N. 1. (In Russian)

[20] Dumitrashko, N.V., Lilienberg, L.A., Antonov, B.A. and Baljan, S.P. (1961) Ancient Glaciations of the Caucasus aud Their Correlation with Glaciations of the Russian Plain. Trudi komisii po izucheniju chetvertichnogo perioda, 19, 170-180. (In Russian)

[21] Tabidze, D.D. (1965) Kodori River Basin Geomorphology, Avtoreferat kand. Disertacii, Tbilisi. (In Russian)

[22] Serebruanny, L.P. and Orlov, A.V. (1989) Moraines as the Source of Glacial Information. Unpublished Manuscript, $235 \mathrm{p}$.

[23] Gobejishvili, R.G. (1995) The Evolution of the Modern Ice Age Glaciers and Mountains of Eurasia in the Late Pleistocene and Holocene. The Thesis of Doctor of Science Degree in Geography. (In Georgian)

[24] Gobejishvili, R., Lomidze, N. and Tielidze, L. (2011) Late Pleistocene (Wurmian) Glaciations of the Caucasus. In: Ehlers, J., Gibbard, P.L. and Hughes, P.D., Eds., Quaternary Glaciations. Extent and Chronology, Elsevier, Amsterdam, 141-147.

[25] Tielidze, L. (2017) Glaciers of Georgia. Springer, Geography of the Physical Environment.

[26] Tielidze, L.G. (2016) Glacier Change over the Last Century, Caucasus Mountains, Georgia, Observed from Old Topographical Maps, Landsat and ASTER Satellite Imagery. The Cryosphere, 10, 713-725. https://doi.org/10.5194/tc-10-713-2016

[27] Johnsen, S.J., Clausen, H.B., Dansgaard, W., Gundestrup, N.S., Hammer, C.U., Andersen, U., Andersen, K.K., Hvidberg, C.S., DahlJensen, D., Steffensen, J.P., Shoji, H., Sveinbjornsdottir, A.E., White, J., Jouzel, J. and Fisher, D. (1997) The $\delta^{18} \mathrm{O}$ Re- 
cord along the Greenland Ice Core Project Deep Ice Core and the Problem of Possible Eemian Climatic Instability. Journal of Geophysical Research: Oceans, 102, 26397-26410. https://doi.org/10.1029/97JC00167

[28] Von Grafenstein, U., Erlenkeuser, H., Brauer, A., Jouzel, J. and Johnsen, S.J. (1999) A Mid-European Decadal Isotope-Climate Record from 15,500 to 5000 Years B.P. Science, 284, 1654-1657. https://doi.org/10.1126/science.284.5420.1654

[29] Mayewski, P.A., Rohling, E.E., Curt Stager, J., Karlen, W., Maasch, K.A., David Meeker, L., Meyerson, E.A., Gasse, F., van Kreveld, S. and Holmgren, K.U. (2004) Holocene Climate Variability. Quaternary Research, 62, 243-255. https://doi.org/10.1016/j.yqres.2004.07.001

[30] Agatova, A.R., Nazarov, A.N., Nepop, R.K. and Rodnight, H. (2012) Holocene Glacier Fluctuations and Climate Changes in the Southeastern Part of the Russian Altai (South Siberia) Based on a Radiocarbon Chronology. Quaternary Science Reviews, 43, 74-93. https://doi.org/10.1016/j.quascirev.2012.04.012

[31] Dyurgerov, M.B. and Meier, M.F. (1997) Year-to-Year Fluctuations of Global Mass Balance of Small Glaciers and Their Contribution to Sea-Level Changes. Arctic and Alpine Research, 29, 392-402. https://doi.org/10.2307/1551987

[32] Gobejishvili, R.G., Tielidze, L., Lomidze, N. and Javakhishvili, A. (2012) Monitoring of the Glaciers against the Background of the Climate Change. Publ. House "Universali”, Tbilisi. (In Georgian)

[33] Tielidze, L. (2016) Modern and Old Glaciers of Georgia. Publishing House "Samshoblo", Tbilisi, 216.

Submit or recommend next manuscript to SCIRP and we will provide best service for you:

Accepting pre-submission inquiries through Email, Facebook, LinkedIn, Twitter, etc. A wide selection of journals (inclusive of 9 subjects, more than 200 journals)

Providing 24-hour high-quality service

User-friendly online submission system

Fair and swift peer-review system

Efficient typesetting and proofreading procedure

Display of the result of downloads and visits, as well as the number of cited articles

Maximum dissemination of your research work

Submit your manuscript at: http://papersubmission.scirp.org/

Or contact ojg@scirp.org 